\title{
REPORTS
}

\section{THIRD ANNUAL MEETING STUDY GROUP ON EUROPEAN LABOR AND WORKING CLASS HISTORY}

The Third Annual Meeting of the Study Group held at the 1974 AHA Meeting in Chicago featured a panel discussion on comparative approaches to labor history with Robert Bezucha of Northwestern University, David Montgomery of the University of Pittsburgh, Martha Vicinus of Indiana University and Reginald Zelnick of the University of California, Berkeley. Attracting many non-European historians, this session stimulated considerable interest in comparative labor history and prompted suggestions that the Study Group expand its range beyond Europe to include all labor historians.

Martha Vicinus, author of a recent book on English working class literature in the nineteenth century, spoke of the value of such a study. She distinguished authentic working class literature, songs, poems and stories written by and for workers, from the popular music hall culture created by the middle class for the consumption of the working class. Truly working class literature, she said, is an excellent historical source for the study of working class life. It is both an expression of workers' consciousness and pride and a means of maintaining and raising that consciousness. In her study she found that changes in the industrial environment were usually reflected in working class literature, in changing words, themes and literary genres.

Robert Bezucha, who has recently published a study on the 1834 Lyons' uprising, considered the impact of legal systems on working class organization. Studying the application of the restrictive French law on associations, he found that it was applied as severely against middle class, cultural and religious societies as against workers' organizations and concluded that the legal repression derived more from the Roman law tradition than from any class bias. This tradition viewed all voluntary associations as potential rivals to the state. Despite or perhaps because of such repression French workers developed a rich associational life with institutions such as the people's jury and tribunal that were parallel to those of the state. Bezucha's finding suggests that the Roman law tradition was a grciater spur to radicalism than was the permissive tolerance of the English common law.

Reginald Zelnick, who has completed the second volume of his study of the workers of St. Petersburg, pleaded for the inclusion of Russian labor history into comparative perspectives, challenging the assumption of Russian exceptionalism. Treating labor radicalism as a function of economic underdevelopment, most Western historians have ignored the fact that Russia before 1914 was becoming a modern industrial nation with a high rate of growth and a concentrated industrial work force similar in structure to that of Germany. Nor was Russian labor legislation significantly different from that of Western nations. Rejecting the economic stage theory of radicalism. Zelnick stressed the formative influence of socialist ideology as transmitted by a radical intelligentsia and political culture.

Asserting that all analysis is necessarily comparative, David Montgomery enumerated several subjects for comparative study that have generally been neglected: the cross-national comparison of workirs in similar industries: the interaction between work and community, production and culture: the stuciy of trade unions, their rules and regulations, as manifestations of working ciass culture: the 
question of ethnicity in the working class so central to American history; and finally the study of mass worker mobilizations, such as the revolutionary upsurge following World War I, on a truly international scale.

\author{
Bernard Moss \\ University of Southern California
}

\title{
ANGLO-AMERICAN LABOR HISTORY AT THE AHA
}

Of the three AHA sessions on working-class history we have been asked to report on, two were remarkably more successful than the third. One of those two, the session on "Working Class Political Culture" containing the especially important essay coauthored by Alan Dawley and Paul Faler, is discussed at length elsewhere.* Of the remaining two sessions, Paul and Thea Thompson's (Essex University, England) presentation of their oral history project on late Victorian and Edwardian England excelled. The panel on "Work and Industrial Discipline in Britain and America" did not.

David Montgomery (Pittsburgh) chaired the session on Work-Time-Discipline and ably attempted to focus the panel on the ways Edward Thompson, in his influential article "Time, Work, and Industrial Capitalism," has suggested industrial capitalism transformed pre-industrial work rhy thms. The panel would, then, try to view this process in three different settings: Puerto Rico in the Great Depression: changing time-schedules and work patterns of American women in recent United States' history; leisure activities in the late Victorian working class outside London. However, not only did these papers' analysis fall short of Thompson's rigorous theoretical example, but the extended presentations did not leave time for comparative discussion.

Montgomery summarized Thompson, tried to give a brief introduction to the other papers, and then discussed the methods adopted by American industrial workers to assert control over their working life. "Industrial time had created not spontaneous, universal obedience to the employers' values..." rather "the stint" and the eight-hour day reflected the workers' concent of a rational, modern distribution of work and time. While Montgomery provided an overview, the rest of the papers failed to address themselves successfully to the theoretical implications of work and timediscipline. Blanca Silvestrini (University of Puerto Rico) spoke on "Work Patterns of Puerto Rican Women in the Rural Industries." Silvestrini presented some interesting material on the family economy of Puerto Rican workers in the 1930s and women's efforts to unionize and assert a public presence in their community, but she neglected to connect her argument with the larger historical debate on the relationship among women's work, their public role, and their power within the family. Similurly, Joanne Vanek (Queens College) in her discussion of "Time Schedules and Work Patterns of Viarricd [American] Women," attacked the conventional assumption that labor-saving devices freed women to enter the workforce. The shift from women's paid labor inside the household (ie. piecework, hoarders), she argued, to paid labor outside the household was achieved at the cost of less :sce p. 13. 